\title{
Virulence of 'atypical' Aeromonas salmonicida isolated from ulcerated flounder Platichthys flesus
}

\author{
Tom Wiklund \\ Institute of Parasitology, Åbo Akademi University, BioCity, Artillerigatan 6, FIN-20520 Åbo, Finland
}

\begin{abstract}
Experiments were conducted to assess the pathogenicity of 2 'atypical' Aeromonas salmonicida strains isolated from ulcerated flounders Platichthys flesus for this species, rainbow trout Oncorhynchus mykiss, roach Rutilus rutilus, and bleak Alburnus alburnus. The pathogenicity of the strains was evaluated by 3 challenge methods: intraperitoneal (i.p.) injection, subdermal (s.d.) injection, and bath exposure. The bath exposure was performed with and without prior abrasion of the skin of the tested flounders. The i.p. injection experiments showed that the tested strain was weakly pathogenic for flounders but non-pathogenic for rainbow trout. The experiments with roach and bleak did not yield conclusive results. The s.d. injection experiment showed that the tested strain induced skin ulcerations in flounders but not in rainbow trout. The bath exposure experiment indicated that the tested strain was able to penetrate the defence mechanisms present in the skin of the flounders only if the skin was abraded prior to the exposure. It was concluded that the 'atypical' A. salmonicida isolated from flounders will not represent any threat to rainbow trout farms in Finnish coastal waters.
\end{abstract}

KEY WORDS: 'Atypical' Aeromonas salmonicida - Virulence Ulcer disease · Flounder - Platichthys flesus

Skin ulcer disease has been reported to occur in different flounder Platichthys flesus (L.) populations in the whole northeast Atlantic area (see Wiklund \& Bylund 1993). The disease is characterized by superficial ulcerations scattered over the whole trunk of the fish. Similar ulcerations have been described in several different fish species such as carp Cyprinus carpio (Fijan 1972), eel Anguilla anguilla (Ohtsuka et al. 1984), goldfish Carassius auratus (Mawdesley-Thomas 1969) and pike Esox lucius (Wiklund 1990). The ulcerations have, in many cases, been associated with infections with 'atypical' Aeromonas salmonicida (Bootsma et al. 1977, Elliott \& Shotts 1980, Kitao et al. 1984, Wiklund 1990).

In a previous study, 'atypical' Aeromonas salmonicida was isolated from the majority of ulcerated floun- ders examined from Finnish coastal waters (Wiklund \& Bylund 1991, Wiklund et al. 1994). However, the phenotypes of these isolates were different from most of the previously described 'atypical' and 'typical' strains of A. salmonicida (Popoff 1984, Wiklund et al. 1994). Although ulcer disease of flounders has been reported for a long time (Johnstone 1905) and numerous investigations on the disease have been conducted during the last 20 years (see Wiklund \& Bylund 1993), the etiology of ulcer disease in flounders is still only imperfectly understood. Very little effort has been made to assess the role of infectious agents in the disease process.

The present work describes the virulence of 'atypical', oxidase-negative Aeromonas salmonicida isolates from flounders, in 4 different fish species.

Materials and methods. Experimental design: Three experiments were performed to investigate the pathogenicity of Aeromonas salmonicida isolates from ulcerated flounders. In the first experiment, the pathogenicity of an isolate was tested by intraperitoneal injection (i.p.) into flounders, rainbow trout Oncorhynchus mykiss, roach Rutilus rutilus, and bleak Alburnus alburnus. In the second experiment, the invasive capacity of 1 bacterial strain was tested on flounders by bath exposure challenge. In the third experiment, the pathogenicity of an isolate was assessed by subdermal (s.d.) injections into flounders and rainbow trout. The bacterial strains used were all 'atypical', cytochrome oxidase-negative A. salmonicida, as described previously (Wiklund \& Bylund 1991, Wiklund et al. 1994).

Experimental fish: All fish used in the experiments were screened for external disease signs and only apparently healthy ones were included in the challenge tests.

The flounders (average size: $24 \mathrm{~cm}$ ) for the i.p. injection experiment and the bath exposure were captured by divers in order to reduce skin damage caused by 
fishing gear. The flounders (average size: $28 \mathrm{~cm}$ ) for the s.d. injection experiments were caught using standing gill nets. All flounders were obtained from the same area of the south coast of Finland.

The fish were transported to the laboratory in plastic bags containirg brackish water $(S=\sim 6 \%$ ) and oxygen. The flounders for the i.p. injection and the bath exposure experiments were housed in plastic tanks with sediments and flow-through brackish water ( $\mathrm{S}=\sim 5 \%$ ). The temperature of the water varied between 17.0 and $20.5^{\circ} \mathrm{C}$. The flounders for the s.d. injection experiments were maintained in plastic tanks with circulating, aerated brackish water at 15 to $16^{\circ} \mathrm{C}$. A part of the recirculated water was replaced every second or third day. The flounders were fed canned mussels.

The roach (average weight: $12 \mathrm{~g}$ ) and bleak (average weight: $12 \mathrm{~g}$ ) were captured by beach seine from fresh water and were transported to the laboratory in plastic bags with water and oxygen. The rainbow trout (average weight $220 \mathrm{~g}$ for the i.p. injection experiment, $35 \mathrm{~g}$ for the s.d. injection experiment) were obtained from a commercial hatchery without any known history of Aeromonas salmonicida infection. The roach, bleak, and rainbow trout (i.p. injection experiments) were kept in plastic tanks with filtered, dechlorinated, flowthrough tap water with a temperature varying between 17 and $18^{\circ} \mathrm{C}$. The rainbow trout used in the s.d. injection experiments were maintained in plastic tanks with recirculating ground water at 14 to $16^{\circ} \mathrm{C}$. The roach, bleak, and rainbow trout were fed commercial trout pellets. All fish were acclimatized for $1 \mathrm{wk}$ prior to the experiments.

The fish used for the i.p and s.d. experiments were bath anaesthetized in benzocaine prior to inoculation.

Intraperitoneal injection: For the i.p. injection experiments with the flounders, isolate 5F23-28, obtained from ulcer tissue of a flounder shortly before the trial, was used. Because the experiment with rainbow trout, roach, and bleak was performed later, the isolate used (5F23-28) in this experiment was passed twice through flounciers to ensure its pathogenicity.

Two day old bacterial cultures grown at $20^{\circ} \mathrm{C}$ in brain heart infusion broth (BHI, Difco Laboratories) supplemented with 5\% newborn calf serum (NCS, Gibco) were centrifuged and washed twice with sterile $0.9 \% \mathrm{NaCl}$. The cells were re-suspended in $0.9 \%$ sterile $\mathrm{NaCl}$. The concentration of viable cells in the inoculum was determined by plating serial 10 -fold dilutions on agar plates (the agar spread technique).

Two groups each of flounders (9 fish group ${ }^{-1}$ ) and rainbow trout (12 fish group $\left.{ }^{-1}\right)$ and three groups of roach (5 to 8 fish group ${ }^{-1}$ ) and bleak ( 4 fish group ${ }^{-1}$ ) were i.p. injected with $0.1 \mathrm{ml}$ of the inoculum and successive 100-fold dilutions of the inoculum. Control groups of each fish species were injected with $0.1 \mathrm{ml}$ sterile $0.9 \% \mathrm{NaCl}$. The different fish groups were kept in separate tanks

Bath exposure: The bacterium used for bath exposure was a strain (26F23-21/1) isolated from the kidney of an ulcerated flounder shortly before the experiment. The bath inoculum was prepared from a $5 \mathrm{~d}$ old culture of the bacterium (grown at $20^{\circ} \mathrm{C}$ ) in BHI supplemented with $5 \%$ NCS. The cells were prepared as described above and resuspended in $1000 \mathrm{ml}$ of $0.9 \%$ sterile $\mathrm{NaCl}$. This inoculum was added to $6 \mathrm{l}$ of brackish water ( $\mathrm{S}=-5 \%$ ) for the exposure.

The flounders used were divided into 4 groups (see Table 2):

The fish in Group 1 (5 flounders) were exposed to the bacterium suspended in brackish water to a concentration of $4.3 \times 10^{7} \mathrm{CFU}$ (coiony-forming units) $\mathrm{ml}^{-1}$. Small areas of the skin on the blind side of the trunk were abraded with a sterile scalpel (referred to as abraded/ exposed group).

The fish in Group 2 (5 flounders) were exposed to the same suspension of the bacterium, as Group 1, but the skin of the fish was not abraded (non-abraded/exposed group).

The fish in Group 3 (5 flounders) were handled in the same way as the fish in Group 1, but no bacteria were added to the water (abraded/non-exposed group).

The fish in Group 4 ( 4 flounders) were kept as control fish and were given the same treatment as the fish in Group 2 but no bacteria were added to the water (non-abraded/non-exposed group).

The flounders in Groups 1 and 2 were exposed for the bacterium for $15 \mathrm{~min}$ with constant aeration of the water. After the exposure, Group 1 and 2 fish were housed in separate tanks and Groups 3 and 4 were housed together in a single tank. For identification, the fish in Group 3 were marked by clipping of the pectoral fin on the eye side. The experiment was terminated after $61 \mathrm{~d}$.

Subdermal injection: The inoculum (freshly passaged isolate $26 \mathrm{~F} 23-21 / 1$ ) was treated as previously described for the i.p. injection experiment. Two groups each of flounders ( 6 fish group ${ }^{-1}$ ) and rainbow trout (15 fish group $^{-1}$ ) were injected subdermally with $0.1 \mathrm{ml}$ of a bacterial suspension. One group of each species was injected with $0.9 \times 10^{7} \mathrm{CFU}_{\text {fish }}^{-1}$ and the other was injected with $0.9 \times 10^{5} \mathrm{CFU}$ fish $^{-1}$. The flounders were injected on the dorsal pigmented side and the rainbow trout were injected dorsally on the left side of the trunk. Each challenge group was maintained in a separate tank. The control group for the experiment with the flounders consisted of 4 specimens maintained in the same tanks (2 per tank) as the flounders receiving the bacterium. The control group of the rainbow trout was kept in a separate tank. Each fish in the control groups received $0.1 \mathrm{ml}$ of sterile $0.9 \% \mathrm{NaCl}$ 
Examination of the experimental fish: After the inoculation, experimental and control fish were visually inspected at regular intervals. Mortalities were recorded and disease signs on all dead and moribund fish were recorded. The dead or moribund fish were removed and when possible examined bacteriologically. Swabs from ulcers, kidney, liver, spleen, and occasionally from peritoneal fluid were streaked on brain heart infusion agar (BHIA, Difco Laboratories) supplemented with $5 \%$ NCS. The inoculated plates were incubated at $20^{\circ} \mathrm{C}$ for $7 \mathrm{~d}$. Any isolated bacterial strains not identical with the inoculum were identified to the species or genus level by standard bacteriological methods. All surviving fish were also inspected for disease signs and then examined bacteriologically as described above.

Results. Intraperitoneal inoculation: The results of the i.p. inoculation experiments on all fish species are given in Table 1.

Flounder: All dead or moribund flounders showed heavily distended abdomens caused by excessive volumes of ascitic fluid. None of the inoculated flounders developed skin ulcers, but small haemorrhages in the skin were observed in 2 specimens. The surviving flounders in Group 2 showed small amounts of ascitic fluid, inflammation at the injection site, and haemorrhages in the peritoneal cavity. One of the flounders in the control group developed an ulcer on the head; otherwise there were no external or internal signs of disease in the fish in the control group.

From the dead and moribund flounders in Group 1 the challenge organism was re-isolated from visceral organs of all 6 specimens sampled for bacterial infec- tion. Among the Group 2 fish, 2 of the dead fish were too deteriorated, when found, to permit satisfactory bacteriological examination. However, the challenge bacterium was recovered from 1 of $2 \mathrm{dead} / \mathrm{moribund}$ fish and from 1 of 4 survivors tested. In the positive survivor, the bacterium was detected in the peritoneal fluid more than $3 \mathrm{wk}$ after the challenge. Mixed colony types, not including 'atypical' Aeromonas salmonicida, were recovered from the ulcer of the ulcerated flounder in the control group.

Rainbow trout: All the dead rainbow trout showed heavy infection with Saprolegnia sp. on the skin and on the fins. Some of the surviving specimens showed haemorrhages in the peritoneum, adipose tissue, and liver in both inoculated groups. Fish in the control group did not show external or internal signs of disease.

The inoculated bacterium was not recovered from the visceral organs of any of the dead rainbow trout. From 2 of the dead rainbow trout unidentified contaminating bacteria were isolated. No bacteria were recovered from the visceral organs of any of the surviving fish.

Roach and bleak: External disease signs in the dead roach and bleak included skin infections with Saprolegnia sp. and haemorrhages in the skin and at the fin bases. In addition, blood in the peritoneal fluid and exophthalmia were observed. The fish in the control groups did not show any external or internal signs of disease.

The inoculated bacteria were not recovered from the visceral organs of the dead roach and bleak, but motile Aeromonas sp., Pseudomonas sp., Enterobacteria, and

Table 1. Intraperitoneal (i.p.) challenge of flounders Platichthys flesus, rainbow trout Oncorhynchus mykiss, roach Rutilus rutilus, and bleak Alburnus alburnus with 'atypical' Aeromonas salmonicida (strain 5F23-28) isolated from an ulcerated flounder

\begin{tabular}{|c|c|c|c|c|c|c|}
\hline Fish species & Group & $\begin{array}{c}\text { No. of } \\
\text { bacterial cells } \\
\text { injected (CFU) }\end{array}$ & $\begin{array}{l}\text { No. of dead } \\
\text { fish } 1 / \text { total } \\
\text { no. of fish }\end{array}$ & $\begin{array}{l}\text { Mean time } \\
\text { to death }(\mathrm{d})\end{array}$ & $\begin{array}{l}\text { Bacterium } \\
\text { re-isolated/no. } \\
\text { of fish tested }\end{array}$ & $\begin{array}{c}\text { No. of fish } \\
\text { developing } \\
\text { ulcers }\end{array}$ \\
\hline \multirow[t]{3}{*}{ Flounder } & 1 & $3.7 \times 10^{8}$ & $9 / 9$ & 5 & $6 / 6$ & 0 \\
\hline & 2 & $3.7 \times 10^{6}$ & $4 / 9$ & 10 & $2 / 6$ & 0 \\
\hline & 3 & $0.9 \% \mathrm{NaCl}$ & $0 / 9$ & - & - & 1 \\
\hline \multirow[t]{3}{*}{ Rainbow trout } & 1 & $3.7 \times 10^{7}$ & $4 / 12$ & 14 & $0 / 11$ & 0 \\
\hline & 2 & $3.7 \times 10^{5}$ & $0 / 12$ & - & $0 / 12$ & 0 \\
\hline & 3 & $0.9 \% \mathrm{NaCl}$ & $0 / 10$ & - & - & 0 \\
\hline \multirow[t]{4}{*}{ Roach } & 1 & $0.8 \times 10^{7}$ & $7 / 8$ & 11 & $0 / 8$ & 0 \\
\hline & 2 & $0.8 \times 10^{5}$ & $7 / 7$ & 17 & $0 / 7$ & 0 \\
\hline & 3 & $0.8 \times 10^{3}$ & $4 / 5$ & 24 & $0 / 2$ & 0 \\
\hline & 4 & $0.9 \% \mathrm{NaCl}$ & $0 / 6$ & - & - & 0 \\
\hline \multirow[t]{4}{*}{ Bleak } & 1 & $0.8 \times 10^{7}$ & $3 / 4$ & 16 & $0 / 4$ & 0 \\
\hline & 2 & $0.8 \times 10^{5}$ & $4 / 4$ & 18 & $0 / 4$ & 0 \\
\hline & 3 & $0.8 \times 10^{3}$ & $3 / 4$ & 24 & $0 / 1$ & 0 \\
\hline & 4 & $0.9 \% \mathrm{NaCl}$ & $0 / 3$ & - & - & 0 \\
\hline
\end{tabular}


unidentified bacteria were isolated. No bacteria were recovered from the visceral organs of the surviving roach and bleak.

Bath exposure: The results of the bath exposure experiment are given in Table 2 .

'Atypical' Aeromonas salmonicida was re-isolated from ulcers and the liver of one of the dead flounders and from the ulcers of the surviving flounders that were abraded/exposed. A. hydrophila was isolated from the visceral organs of another of the dead fish, and motile Aeromonas sp. was isolated from the ulcers on this fish. One of the dead fish was too deteriorated, when found, to permit bacteriological examination. Bacteria were not isolated from the visceral organs of the 2 surviving fish nor from the visceral organs of the group that was non-abraded/exposed.

'Atypical' Aeromonas salmonicida was isolated from the ulcers that developed on flounders in the groups that were abraded/non-exposed and non-abraded/ non-exposed. Bacteria were not recovered from the visceral organs of ulcerated and non-ulcerated flounders in these 2 groups.

Subdermal inoculation: The results of the subdermal inoculation experiments are given in Table 3 .
All injected flounders showed haemorrhages in the skin and severe inflammation and muscle necrosis at the injection site. Some of the flounders given the higher bacterial dose also developed ascites and haemorrhages in the liver and kidney. None of the control flounders showed any signs of disease and the only rainbow trout to show disease signs (inflammation at the injection site) was the one that died.

The inoculated bacterium was re-isolated from the injection site of all but 1 of the 12 inoculated flounders and from the visceral organs of 2 of the dead or moribund flounders. No bacteria were recovered from the control flounders.

'Typical' Aeromonas salmonicida was isolated from the dead rainbow trout. Bacteria could not be recovered from any of the surviving rainbow trout.

Discussion. 'Atypical', cytochrome oxidase-negative Aeromonas salmonicida has frequently been isolated from ulcers on diseased flounders in the past. However, such strains of the bacterium are rarely isolated from visceral organs of ulcerated flounders (Wiklund \& Bylund 1991, Wiklund \& Dalsgaard unpubl. data), suggesting that the involvement of the bacterium in the disease process is primarily external. This is in accor-

Table 2. Bath challenge of flounders Platichthys flesus with 'atypical' Aeromonas salmonicida (strain 26F23-21/1) isolated from an ulcerated flounder. abr: skin abraded; non-abr: skin not abraded; exp: exposed to bacterium; non-exp: not exposed to bacterium.

\begin{tabular}{|c|c|c|c|c|c|c|}
\hline Group & Treatment & $\begin{array}{c}\text { Concentration of } \\
\text { bacterial cells } \\
\left.\text { (CFU ml }]^{-1}\right)\end{array}$ & $\begin{array}{c}\text { No. of dead } \\
\text { fish }^{d} / \text { total } \\
\text { no. of fish tested }\end{array}$ & $\begin{array}{l}\text { Mean time } \\
\text { to death }(\mathrm{d})\end{array}$ & $\begin{array}{l}\text { Bacterium } \\
\text { re-isolated/no. } \\
\text { of fish tested }\end{array}$ & $\begin{array}{c}\text { No. of fish } \\
\text { developing } \\
\text { ulcers }\end{array}$ \\
\hline 1 & abr/exp & $4.3 \times 10^{7}$ & $3 / 5$ & 32 & $2 / 4$ & 4 \\
\hline 2 & non-abr/exp & $4.3 \times 10^{7}$ & $0 / 5$ & - & $0 / 5$ & 0 \\
\hline 3 & abr/non-exp & - & $0 / 5$ & - & $1^{c / 1}$ & 1 \\
\hline 4 & non-abr/non-exp & - & $0 / 4$ & - & $2^{c / 2}$ & 2 \\
\hline
\end{tabular}

Table 3. Subdermal (s.d.) challenge of flounders Platichthys flesus and rainbow trout Oncorhynchus mykiss with 'atypical' Aeromonas salmonicida (strain 26F23-21/1) isolated from an ulcerated flounder

\begin{tabular}{|c|c|c|c|c|c|c|}
\hline Fish specles & Group & $\begin{array}{c}\text { No. of } \\
\text { bacterial cells } \\
\text { injected (CFU) }\end{array}$ & $\begin{array}{l}\text { No. of dead } \\
\text { fish } / \text { total } \\
\text { no. of fish }\end{array}$ & $\begin{array}{l}\text { Mean time } \\
\text { to death (d) }\end{array}$ & $\begin{array}{l}\text { Bacterium } \\
\text { re-isolated/no. } \\
\text { of fish tested }\end{array}$ & $\begin{array}{c}\text { No. of fish } \\
\text { developing } \\
\text { ulcers }\end{array}$ \\
\hline Flounder & $\begin{array}{l}1 \\
2 \\
3\end{array}$ & $\begin{array}{c}0.9 \times 10^{7} \\
0.9 \times 10^{5} \\
0.9 \% \mathrm{NaCl}\end{array}$ & $\begin{array}{l}3 / 6 \\
0 / 6 \\
0 / 4\end{array}$ & $\begin{array}{c}15 \\
- \\
-\end{array}$ & $\begin{array}{c}6 / 6 \\
5 / 6 \\
-\end{array}$ & $\begin{array}{l}6 \\
6 \\
0\end{array}$ \\
\hline Rainbow trout & $\begin{array}{l}1 \\
2 \\
3\end{array}$ & $\begin{array}{c}0.9 \times 10^{7} \\
0.9 \times 10^{5} \\
0.9 \% \mathrm{NaCl}\end{array}$ & $\begin{array}{l}17 / 1.5 \\
0 / 15 \\
0 / 12\end{array}$ & $\begin{array}{l}15 \\
- \\
-\end{array}$ & $\begin{array}{c}0 / 15 \\
0 / 15 \\
-\end{array}$ & $\begin{array}{l}0 \\
0 \\
0\end{array}$ \\
\hline
\end{tabular}


dance with the results obtained in the present pathogenicity tests. The flounders inoculated i.p. with 'atypical' A. salmonicida did not develop skin ulcerations. In contrast, all flounders inoculated s.d. and the majority of the flounders abraded/exposed developed ulcers at the site of injection or skin abrasion. These results strongly indicate that the ulcers in flounders are due to a successful external colonization of the skin by the bacterium rather than to invasion of the dermis from some earlier internal infection. A similar etiology has also been reported for carp erythrodermatitis (Bootsma et al. 1977).

The results from the i.p. injection experiment indicated that the tested strains were weakly pathogenic for flounders and non-pathogenic for rainbow trout. Although most of the challenged roach and bleak died in the i.p. injection experiment, the inoculated bacterium was not re-isolated from the dead fish. No firm conclusions can therefore be drawn on the pathogenicity of the tested strain for roach and bleak. Opportunistic pathogens (Aeromonas sp., Pseudomonas sp., Enterobacteria or unidentified bacteria) were isolated from the dead fish, but whether these organisms were responsible for the mortalities is unknown. It is possible that the injected bacterium paved the way for infection with the opportunistic pathogens. Opportunistic pathogens (e.g. A. hydrophila) have also been isolated from fish challenged with 'atypical' A. salmonicida (Whittington \& Cullis 1988). Also, it has been reported that 'typical' $A$. salmonicida can induce a suppression as well as an activation of different parts of the non-specific immune system in salmon Salmo salar (Møyner et al. 1993). It is therefore conceivable that the injected 'atypical' strain exerted an immunosuppressive effect on the challenged roach and bleak. On the other hand, other mechanisms, like stress, could have contributed to the mortalities.

The s.d. inoculation experiments clearly showed that the injected bacterial strain was able to induce ulcerations in flounders but not in rainbow trout. The source of the 'typical' Aeromonas salmonicida isolated from one rainbow trout in the s.d. injection experiment was most probably other rainbow trout being held in the same (recirculating) aquarium system as the challenged fish. These trout were experiencing an outbreak of furunculosis. The 'host specificity' of the strains isolated from ulcerated flounders is in accordance with earlier observations that 'atypical' A. salmonicida isolated from ulcerated carp are more virulent for cyprinids than for rainbow trout (Obradovic 1983). Also, Pedersen et al. (1994) reported that the 'atypical', cytochrome oxidase-negative $A$. salmonicida isolated from ulcerated turbot showed low or no pathogenicity for salmonids. Car- son \& Handlinger (1988), however, found that 'atypical' $A$. salmonicida strains isolated from ulcerated goldfish were extremely pathogenic for salmonids. It is obvious, therefore, that not all strains of 'atypical' A. salmonicida lack the ability to cause disease in salmonids.

The bath challenge experiment showed that the invasive capacity of the bacterial strain tested was limited and that prior abrasion of the skin of the flounder clearly enhanced the ability of the bacterium to cause ulcers. Although the results indicated that skin injury facilitates the development of ulcers, the survival of 1 flounder in the abraded/challenged group in the bath challenge experiment also indicated that skin injuries in flounders exposed to the bacterium do not necessarily predispose to the development of ulcers. However, it is not known whether the surviving flounder possessed antibodies against the 'atypical' Aeromonas salmonicida used for the challenge as a result of previous contact with the bacterium. The association between skin injuries caused by fishing gear and skin ulcerations in flounders has previously been discussed by Vethaak (1993) and Wiklund \& Bylund (1993). Although skin injuries obviously predispose to the condition, other factors (sex, fish size, season, variations in salinity) may also be involved.

The development of ulcers on fish in the abraded/non-exposed and non-abraded/non-exposed groups shows that the flounders can be extremely sensitive to handling. It is possible that the skin of these flounders was already injured during the catching of the fish. The source of the isolated bacterium is unknown. It could have originated from the water or the sediment, or alternatively they might have been introduced into the tanks used for the experiments together with the flounder. The isolates obtained from the ulcers of these flounders were similar to the strain used in the challenge test.

The apparent non-pathogenicity of the 'atypical' Aeromonas salmonicida flounder isolate for rainbow trout indicates that the bacterium is not likely to represent a threat to rainbow trout farmed in Finnish coastal water areas. In Denmark, a similar bacterium was isolated from ulcerated farmed turbot Scophthalmus maximus (Pedersen et al. 1994). It is conceivable, therefore, that the strains isolated from flounders could pose a threat to future flatfish farming in the Baltic Sea.

Acknowledgements. I thank Olle Lerche for his assistance. I also thank Göran Bylund, Michael Courtney, and Inger Dalsgaard for comments on the manuscript. This work was carried out with financial support from the Oskar Öflunds foundation, Stiftelsens för §̊o Akademi Forskningsinstitut, Svenska Kulturfonden and Åbo Akademi University. 


\section{LITERATURE CITED}

Bootsma R, Fijan N, Blommaert J (1977) Isolation and preliminary identification of the causative agent of carp erythrodermatitis. Vet Arh 47:291-302

Carson J, Handlinger J (1988) Virulence of the aetiological agent of goldfish ulcer disease in Atlantic salmon, Salmo salar L. J Fish Dis 11:471-479

Elliott DG, Shotts EB Jr (1980) Aetiology of an ulcerative disease in goldfish Carassius auratus (L.): microbiological examination of diseased fish from seven locations. J Fish Dis $3: 133-143$

Fijan NN (1972) Infectious dropsy in carp - a disease complex. Symp zool Soc Lond 30:39-51

Johnstone $J$ (1905) Internal parasites and diseased conditions of fishes. Lancashire Sea-Fish Lab Rep 1904 13:98-120

Kitao T, Yoshida T, Aoki T, Fukudome M (1984) Atypical Aeromonas salmonicida, the causative agent of an ulcer disease of eel occurred in Kagoshima prefecture. Fish Pathol 19:113-117

Mawdesley-Thomas LE (1969) Furunculosis in the goldfish Carassius auratus (L.). J Fish Biol 1:19-23

Møyner K, Røed KH, Sevatdal S, Heum M (1993) Changes in non-specific immune parameters in Atlantic salmon, Salmo salar L., induced by Aeromonas salmonicida infection. Fish Shellfish Immunol 3:253-265

Obradovic J (1983) The dose of infectious material necessary for development of carp erythrodermatitis in some freshwater fish. Vet Glas 37:83-88

Ohtsuka H, Nakai T, Muroga K, Jo Y (1984) Atypical Aero-

Responsible Subject Editor: T Evelyn, Nanaimo, B.C., Canada monas salmonicida isolated from diseased eels. Fish Pathol 19:101-107

Pedersen K. Kofod H. Dalsgaard I, Larsen JL (1994) Isolation of oxidase-negative Aeromonas salmonicida from diseased turbot Scophthalmus maximus. Dis aquat Org 18: $149-154$

Popoff M (1984) Genus IIl. Aeromonas Kluyver and Van Niel 1936, $398^{\text {AL }}$. In: Krieg NR, Holt JG (eds) Bergey's manual of systematic bacteriology, Vol 1. Williams and Wilkins, Baltimore, p 545-548

Vethaak D (1993) Fish disease and marine pollution. PhD thesis, University of Amsterdam

Whittington RJ, Cullis B (1988) The susceptibility of salmonid fish to an atypical strain of Aeromonas salmonicida that infects goldfish, Carassius auratus (L.), in Australia. J Fish Dis 11:461-470

Wiklund T (1990) Atypical Aeromonas salmonicida isolated from ulcers of pike, Esox lucius L. J Fish Dis 13:541-544

Wiklund T, Bylund G (1.991) A cytochrome oxidase negative bacterium (presumptively an atypical Aeromonas salmonicida) isolated from ulcerated flounders (Platichthys flesus (L.f) in the northern Baltic Sea. Bull Eur Ass Fish Pathol 11: $74-76$

Wiklund T, Bylund G (1993) Skin ulcer disease of flounder Platichthys flesus in the northern Baltic Sea. Dis aquat Org 17:165-174

Wiklund T, Dalsgaard I, Eerola E, Olivier G (1994) Characteristics of 'atypical', cytochrome oxidase negative Aeromonas salmonicida isolated from ulcerated flounders (Platichthys flesus (L.)). J appl Bacteriol 76:511-520

Manuscript first received: May 10, 1994

Revised version accepted: November 7, 1994 